Original article

\title{
Populations of Cephalanthera damasonium (Mill.) Druce on the hills of the right bank of the River Dnieper (in Forest Steepe vegetation of Ukraine)
}

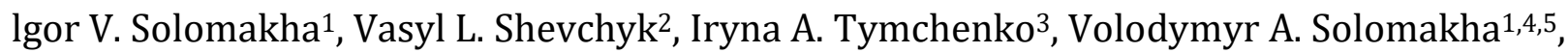 \\ Tetyana S. Dvirna ${ }^{3 *}$ \\ ${ }_{1}^{1}$ Institute of Agroecology and Environmental Management of NAAS, Kiev, 12 Metrologichna Str., 03143, Ukraine \\ ${ }^{2}$ Kyiv National Taras Shevchenko University, NSC Institute of Biology and Medicine, Kiev-601, 64/13 Volodymyrska Str., 01601, Ukraine \\ ${ }_{3}^{3}$ M.G. Kholodny Institute of Botany, National Academy of Sciences of Ukraine, Kiev, 2 Tereschenkivska Str., 01601, Ukraine \\ ${ }^{4}$ Vasyl' Stus Donetsk National University, Vinnytsya, 21, 600-richchya Str., 2100, Ukraine \\ ${ }^{5}$ National Scientific Center "Institute of Beekeeping named after P.I. Prokopovich", NAAS, Kiev, 19 Academician Zabolotnogo Str., \\ 03143, Ukraine \\ E-mail address (*corresponding author): dvirna_t@ukr.net \\ ORCID iD: lgor V. Solomakha: https://orcid.org/0000-0001-8853-2973; Vasyl L. Shevchyk: https://orcid.org/0000-0002-3696- \\ 1968; Iryna A. Tymchenko: https://orcid.org/0000-0001-7505-3164; Volodymyr A. Solomakha: https://orcid.org/0000-0003- \\ 3975-5366; Tetyana S. Dvirna: https://orcid.org/0000-0002-9279-9766
}

\begin{abstract}
As a result of studying the vegetation cover of artificial (possibly spontaneous) tree plantations on the hills of the right bank of the River Dnieper in the Forest-Steppe of Ukraine we discovered the formation of natural populations of Cephalanthera damasonium (Mill.) Druce. Information on the growth of this species was previously presented (more than 80 years ago) by F. Gryn (samples of which are in The National Herbarium of Ukraine, Kiev), who noted its distribution in these locations. The ecological and coenotic features of the distribution of this species as a part of available populations in the communities of classes CarpinoFagetea sylvaticae, Quercetea pubescentis, Crataego-Prunetea, Alno glutinosae-Populetea albae have been studied. The largest eight new populations of $C$. damasonium have been identified on the eastern border of Ukraine. Habitat conditions, number and structure of all new populations were determined. Micropopulations of the species occupy an area from several to $750 \mathrm{~m}^{2}$ with a total population of more than 1,200 specimens. The ontogenetic spectrum is right-sided, with a dominance of generative individuals, and their share is $4 / 5$ of the total number of individuals. The peculiarity of this locality is the high number of individuals in most of these populations, which may be due to favourable ecological-coenotic conditions and the absence of intensive anthropogenic influences. The identified habitats of the study species need protection.
\end{abstract}

KEY WORDS: Cephalanthera damasonium, River Dnieper, Forest-Steppe of Ukraine, population structure, number and density of individuals

ARTICLE HISTORY: received 26 December 2019; received in revised form 25 May 2020; accepted 26 May 2020

\section{Introduction}

The genus of Cephalanthera contains about 20 species world-wide (WCSP, 2020). Almost all of them are distributed in the temperate zone of EuroAsia, some are in North Africa, only one saprophytic species occurs in north west North America, and four species are endemic to China (FLORA OF CHINA,
2009; WCSP, 2020). In the flora of Ukraine this genus is represented by 3 species: Cephalanthera damasonium (Mill.) Druce, C. longifolia (L.) Fritsch, and C. rubra (L.) Rich.

Cephalanthera damasonium is of prime interest. The total area of $C$. damasonium is temperate subMediterranean Eurasia, and the species is widespread but rarely abundant (RANKOU, 2011). It is 
a rare species listed in Red Data Books in: Ukraine (RED Book of UKraine, 2009), Russia (Red Book of THE Russian FEDERATion, 2008), Moldova (THE RED Book of THE REPUbliC of Moldova, 2015) and Red Lists of European countries: England (STROH ET AL., 2014), Poland (ZARZYCKI \& SZELĄG, 2006) etc. In Ukraine the species is distributed in the Carpathians, Polissya, West Podillya, Forest-Steppe (rare) and Crimea (CHORNEJ ET AL., 2003; TYMCHENKO, 2007). Most localities of this species are concentrated in the west of Ukraine and in the Crimean Mountains. It grows in coniferous, mixed and deciduous forests, rarely on forest edges, in grassland, and mostly on limestone soils with high humus content in shade or semi-shade (RED DATA BOOK OF UKRAINE, 2009).

The Ukraine is the north eastern limit of the distribution of $C$. damasonium, although a further north eastern locality of $C$. damasonium in the Bryansk region of Russia was discovered in 2019 (SEMENISHCHENKOV, 2019). In Ukraine the north eastern site of the species of $C$. damasonium is in the Left Bank Forest Steppe in the Poltava region in a forested area near the village of Dykan'ka (Poltava region). This finding was dated 1938 (GRYN, 1946), later that location was confirmed (NEDORUB, 1998; BAYRAK \& STETSIYK, 2005). Another north eastern locality of this species is the habitat on the northern outskirts of the city of Rzhyshchiv, in the region of Kiev (Right bank Forest Steppe), as evidenced by two herbarium specimens stored in the National Herbarium of Ukraine $(K W)$ and collected by F. Gryn in 1932 and 1937. As a result of a study of the Dnieper Hills vegetation on the right bank of the Dnieper (in the district of Kaniv reservoir) in the Forest-Steppe of Ukraine, another locality of the species was discovered (SOLOMAKHA, 2019). Unfortunately, due to the lack of precise, geographical coordinates for the location of the species found in the Right bank Forest Steppe which was found in the 1930s, it was not possible to determine whether it was found in the same location. However, the absence of this species in other habitats nearby suggests that this location is unique because it is located a considerable distance from the main continuous area of C. damasonium in the west.

The botanical literature about the populations of $C$. damasonium on the edge of its distribution (in the Forest-Steppe of Ukraine) is fragmentary or very generalized. Therefore, the purpose of this research was to investigate the peculiarities of $C$. damasonium in terms of its ecological and coenotic nature and population structure on the edge of its range in the area where it was detected.

\section{Materials and methods}

\subsection{Study area}

The investigated habitats of $C$. damasonium were found near the suburban massif of Dniprovs'ki kruchi between the villages of Stayky and Hrebeni of the Kagarlyk district of the Kiev region. Most populations of $C$. damasonium were found on the hills of the right bank of the River Dnieper (description №s 2-8). One population is in the ravine system on the opposite side of the Ukrayinka - Rzhyshchiv road, in the territory of the Rzhyshchivs'kyy reserve of national importance (square 25 of Staykivs'k forestry of State Enterprise „Rzhyshchiv forestry” (description № 1).

According to the physical-geographical zoning of Ukraine the studied territory is located within the Kyiv altitude region of the Podilsk-Dnieper land of Forest-Steppe vegetation zone of the East European Plain (ECOLOGICAL ENCYCLOPEDIA, 2006). By geobotanical zoning the territory belongs to the Northern Right Bank Dnieper region of hornbeam-oak, oak forests, steppe meadow and meadow-steppes of Ukrainian forest-steppe subprovince of Eastern European Forest-Steppe province oak forests, steppe meadow and meadow steppes of Forest-Steppe sub-region (zone) of Eurasian steppe region (NATIONAL ATLAS OF UKRAINE, 2008).

All the surveyed localities of Cephalanthera damasonium were confined to the north-eastern macro-slope of the native bank of the Dnieper. There is a great variation in the lithological composition and an inconsistent occurrence of sand-clay rocks of the Paleogene within this territory. A significant excess surface above the Dnieper and the presence of several aquifers promote active development of landslides and erosion surface slope. The region receives an average annual rainfall of $500-550 \mathrm{~mm}$. The maximum rainfall is in June - July and mostly in the form of showers, which cause erosion (CLIMATE OF UKRAINE, 2003). There are different variations of grey forest soils under deciduous forests.

This study presents the peculiarities of the distribution of this species in the Dnieper Hills where a number of interesting populations were found in different ecological conditions (Table 1). 
Table 1. Characteristics of the population plots

\begin{tabular}{|c|c|c|}
\hline $\begin{array}{c}\text { № of } \\
\text { population }\end{array}$ & $\begin{array}{c}\text { Geographical } \\
\text { coordinates }\end{array}$ & Location \\
\hline 1 & $\begin{array}{l}50.052680 \mathrm{~N} \\
30.924254 \mathrm{E}\end{array}$ & Terraced ravine slope, upper and middle parts $\left(20-25^{\circ}\right.$ steepness $)$ \\
\hline 2 & $\begin{array}{l}50.052462 \mathrm{~N} \\
30.938208 \mathrm{E} \\
\end{array}$ & Sliding terrace on a steep slope to the bank of the Dnieper River \\
\hline 3 & $\begin{array}{l}50.0520141 \mathrm{~N} \\
30.9376938 \mathrm{E}\end{array}$ & Sliding terrace on a steep slope to the bank of the Dnieper River \\
\hline 4 & $\begin{array}{l}50.0520768 \mathrm{~N} \\
30.9410030 \mathrm{E}\end{array}$ & Steep slope $\left(45^{\circ}\right.$ steepness) of eastern exposure to the bank of the Dnieper River \\
\hline 5 & $\begin{array}{l}50.0512383 \mathrm{~N} \\
30.9418157 \mathrm{E}\end{array}$ & Drain plot on a steep slope to the Dnieper River into which water flows \\
\hline 6 & $\begin{array}{l}50.0471230 \mathrm{~N} \\
30.9450082 \mathrm{E}\end{array}$ & The steep slope ( $45^{\circ}$ steepness) of the northern exposure to the bank of the Dnieper River \\
\hline 7 & $\begin{array}{l}50.052077 \mathrm{~N} \\
30.940730 \mathrm{E}\end{array}$ & The steep slope ( $45^{\circ}$ steepness) of the northern exposure to the bank of the Dnieper River \\
\hline 8 & $\begin{array}{l}50.065457 \mathrm{~N} \\
30.921393 \mathrm{E} \\
\end{array}$ & The steep slope $\left(45^{\circ}\right.$ steepness) of western exposure to the bank of the Dnieper River \\
\hline
\end{tabular}

\subsection{Data and methods}

The research into the coenotic conditions and structure of the populations of Cephalathera damasonium in a new locality on the right bank of the River Dnieper (in the district of Kaniv reservoir) in the Forest-Steppe of Ukraine was conducted during June-July 2019.

Reconnaissance studies were performed using the route-floristic and geobotanical methods (BRAUN-BlanQueT, 1964; ABDUloEVA \& SOLOMAKHA, 2011). Taxonomic names are given according to the nomenclatural checklist (MOSYAKIN \& FEDORONCHUK, 1999). Collection of herbarium specimens and their processing was carried out according to the standard classical method (SKVORCZOV, 1977; CHOPYK ET AL., 1999). Descriptions of vegetation plots that include rare species were carried out in accordance with generally accepted methods (MYRKYN ET AL., 2001). Class code and syntaxons are given by MUCINA ET AL., (2016). The sample plots were laid out within the natural limits of the phytocoenoses. These areas have a different size due to the uneven form of the vegetation. A total of eight complete geobotanical descriptions within the plots were made for this orchid. The descriptions cover all coenotically different variants of C. damasonium loci over an area about 100 hectares.

To assess the state of the populations of C. damasonium we determined population parameters such as: the area occupied by the population, number and density of individuals, ontogenetic (age) and vitality structure of each population. These parameters indicate the current state of these populations.

The life history (ontogenesis) of $C$. damasonium, as with other terrestrial orchids, has the main ontogenetic stages of: seed, protocorm, seedling, vegetative young (juvenile, immature), vegetative adult (virginile), generative and senescent individuals (VAKHRAMEEVA ET AL., 2008; SHEFFERSON ET AL., 2020). The study of ontogenetic structure took into account individuals of four main ontogenetic stages: juvenile (j), immature (im), virginile (v) and generative $(\mathrm{g})$. The individuals of different ontogenetic stages were distinguished by considering the qualitative and quantitative parameters such as habit of the plant, height, number and size of leaves, and the presence of flowers, as in our previous studies (TYMCHENKO, 2007). The protocorm and seedling of this orchid are underground so they were not considered in the study.

Vitality structure studied by ZLOBIN (1989; 2018) used a one-dimensional approach. The vitality of individuals was evaluated by an indicative morphometric feature and such a feature for $C$. damasonium was the height of the individual. 30 generative individuals were defined according to their vitality classes on the basis of the height of the individuals. To determine which vitality class each individual belonged to be calculated the average (arithmetic mean) height and its confidence intervals. All individuals that fell within the range of $\mu+t_{0,05} S \mu$ to $\mu-t_{0,05} S \mu$ were intermediate (b) class, individuals with certain morphometric features $>$ $\mu+t_{0,05} S \mu$ - were higher (a), and $<\mu-t_{0,05} S \mu-$ lower (c) vitality class, where $\mathrm{x}$ is the arithmetic mean, $t_{0,05}$ is the value of the Student's t-test at $p=0,05$ and $S \mu$ is the standard error of the mean. By analyzing the range of plants by their vitality classes we determined the vitality type of the population, for which the values of the index was determined as $Q$. If $Q=1 / 2(a+b)>c$, then the population was prosperous, $\mathrm{Q}=1 / 2(\mathrm{a}+\mathrm{b})=\mathrm{c}-$ in 
equilibrium, $Q=1 / 2(a+b)<c$ - depressive, where $a, b, c$ - are the frequencies of the corresponding vitality classes.

The herbarium specimens of C.damasonium which were collected were submitted to the National Herbarium of Ukraine in Kiev $(K W)$.

\section{Results and discussion}

\subsection{Habitat conditions}

In Ukraine, the species is found growing in communities of order Fagetalia sylvaticae Pawłowski 1928, Carpinetalia betuli P. Fukarek 1968 of class Carpino-Fagetea sylvaticae Jakucs ex Passarge 1968, order Quercetalia pubescenti-petraeae Klika 1933 of class Quercetea pubescentis Doing-Kraft ex Scamoni et Passarge 1959, order Erico-Pinetalia Horvat 1959 nom. conserv. propos. of class EricoPinetea Horvat 1959, rarely in communities of union Bromion erecti Koch 1926 of class FestucoBrometea Br.-Bl. et Tx. ex Soo 1947. The species is diagnostic for communities of the union Fagion sylvaticae Luquet 1926 of class Carpino-Fagetea sylvaticae (RED DATA BOOK OF UKRAINE, 2009). In the mountains it can grow at an altitude of up to 1500 m. C. damasonium favours fertile soils with medium humidity and high $\mathrm{pH}$ content.

Most populations are distributed in dark plantations of Carpinus betulus where herb cover is virtually absent. They occur both solitarily and in numerous populations. The new location is of interest due to the significant representation of
C. damasonium there. In this unique habitat eight local populations with different numbers of individuals in each population (from 10 to 500) were identified, which were at a distance of 100 to 1500 meters from one another. This allowed us to confirm that the existing ecological and coenotic conditions were optimal for growth and development of the $C$. damasonium individuals. In the absence of, or little, anthropogenic impact, these populations have the possibility of remaining in these areas for a long time.

The localities of C.damasonium have the characteristics of ecotones. Therefore, it is difficult to provide a clear syntaxonomic interpretation of these phytocoenoses. This is due to the rather complex history of vegetation formation in the Dnieper hills (the existence of artificially planted forests, spontaneously formed tree-shrub communities and coenoses of natural forest vegetation, which corresponds to the ecological features of these habitats). Based on our assessment of the existing vegetation, it is possible to note the complete naturalness and minimal impact of anthropogenic factors on these groups of plants. Most of the studied areas where the populations of this species were distributed are difficult to access, due to the significant steepness of ravine systems and Dnieper Hills. For confirmation, we provide a phytocoenotic table of vegetation descriptions which included $C$. damasonium, where we pre-refer them to syntaxes (Table 2) and also present the diagnostic species complexes of several classes of forest vegetation.

Table 2. Descriptions of forest vegetation with Cephalanthera damasonium

\begin{tabular}{|c|c|c|c|c|c|c|c|c|c|}
\hline Description number & 1 & 4 & 5 & 6 & 8 & 3 & 2 & 7 & \multirow{4}{*}{$\begin{array}{l}\text { Mnemocode } \\
\text { of classes }\end{array}$} \\
\hline Density of the stand of trees & 0.9 & 0.6 & 0.6 & 0.7 & 0.9 & 0.8 & 0.6 & 0.7 & \\
\hline Density of the bushes & - & 0.2 & 0.1 & 0.4 & 0.1 & 0.4 & 0.4 & 0.4 & \\
\hline Projective coverage of herb layer & 2 & 40 & 10 & 25 & 10 & 5 & 15 & 40 & \\
\hline Syntax numbers ${ }^{* *}$ & \multicolumn{2}{|c|}{1} & \multicolumn{2}{|c|}{2} & \multicolumn{2}{|c|}{3} & \multicolumn{2}{|c|}{4} & \\
\hline Cephalanthera damasonium & 2 & 1 & 2 & 3 & + & 3 & 5 & + & FAG \\
\hline Carpinus betulus (A) & 50 & 15 & 20 & 35 & 60 & - & - & - & FAG \\
\hline Carpinus betulus (B) & - & 1 & + & 1 & + & - & - & - & FAG \\
\hline Populus nigra (A) & 5 & 15 & - & 5 & - & - & - & - & POP \\
\hline Aegopodium podagraria & - & 30 & - & 5 & + & - & - & 10 & POP ROB FAG \\
\hline Galium odoratum & - & - & + & 15 & + & - & - & + & FAG \\
\hline Carex digitata & - & 1 & - & 1 & - & - & - & + & FAG \\
\hline Glechoma hirsuta & - & - & - & + & + & - & - & - & FAG \\
\hline Pulmonaria obscura & - & 6 & - & - & + & - & - & - & FAG \\
\hline Cerasus avium (B) & - & + & - & - & 1 & - & + & - & POP FAG RHA \\
\hline Acer platanoides (B) & - & - & - & - & - & 2 & 5 & 7 & FAG \\
\hline Crataegus pseudokyrtostylla (B) & - & - & - & - & - & 2 & 1 & - & \\
\hline Carex muricata & - & - & - & - & + & 1 & + & - & FAG \\
\hline Populus alba (C) & - & - & - & - & - & + & + & - & POP \\
\hline Quercus robur $(\mathrm{C})$ & - & - & - & - & - & + & + & - & FAG POP \\
\hline Pinus sylvestris $(\mathrm{A})$ & - & - & - & - & - & 5 & + & - & ERI PIC PYR \\
\hline Pyrus communis $(\mathrm{A})$ & - & - & - & - & - & 5 & - & 5 & FAG POP PUB \\
\hline Swida sanguinea (B) & - & 1 & + & 3 & - & 10 & 10 & 5 & \\
\hline
\end{tabular}




\begin{tabular}{|c|c|c|c|c|c|c|c|c|c|}
\hline Euonymus verrucosus (B) & - & 10 & + & + & 1 & + & + & - & FAG PUB \\
\hline Viola hirta & - & 1 & 5 & + & 3 & 1 & - & - & PUB \\
\hline Brachypodium pinnatum & - & - & 1 & - & + & + & + & - & BRA FES GER \\
\hline Acer tataricum $(\mathrm{B})$ & - & - & + & + & + & + & + & - & PUB \\
\hline Viburnum opulus (B) & - & - & + & + & - & + & + & 1 & POP RHA \\
\hline Acer platanoides $(\mathrm{C})$ & - & - & - & - & + & + & - & - & FAG \\
\hline Corylus avellana (B) & - & - & 1 & 20 & 1 & - & + & 5 & RHA \\
\hline Juglans regia (B) & - & - & - & + & - & - & + & - & POP \\
\hline Frangula alnus (B) & - & - & - & + & - & - & - & + & ALN POP \\
\hline Rubus caesius & - & - & + & - & - & - & + & + & POP ROB \\
\hline Populus nigra (B) & - & 1 & - & - & - & - & - & - & POP \\
\hline Ulmus laevis $(\mathrm{A})$ & - & - & 10 & - & - & - & - & - & POP ROB \\
\hline Populus tremula (B) & - & - & 1 & - & - & - & - & - & FAG ASA \\
\hline Populus canescens (B) & - & - & - & - & - & - & - & 5 & POP \\
\hline Equisetum hyemale & - & - & + & - & - & - & - & 15 & POP \\
\hline Acer campestre (B) & - & - & + & - & - & - & - & + & FAG POP RHA \\
\hline Carex rhizina & - & - & - & - & 5 & - & - & - & BRA MOL \\
\hline Geranium robertianum & - & - & - & - & + & - & - & - & FAG \\
\hline Campanula bononiensis & - & - & - & - & + & - & - & - & PUB \\
\hline Scutellaria altissima & - & - & - & - & + & - & - & - & PUB \\
\hline Quercus robur $(\mathrm{A})$ & - & - & - & - & - & 25 & - & - & FAG POP \\
\hline Acer platanoides $(\mathrm{A})$ & - & - & - & - & - & 10 & - & - & FAG \\
\hline Circaea lutetiana & - & - & - & - & - & + & - & - & FAG \\
\hline Populus alba (A) & - & - & - & - & - & - & 30 & - & POP \\
\hline Tilia cordata $(\mathrm{B})$ & - & - & - & - & - & - & + & - & FAG \\
\hline Fraxinus excelsior (B) & - & - & - & - & - & - & + & - & FAG \\
\hline Alliaria petiolata & - & - & - & - & - & - & 7 & - & FAG POP \\
\hline Robinia pseudoacacia (B) & - & - & - & - & - & - & 5 & - & ROB \\
\hline Rosa sp. & - & - & - & - & - & - & + & - & \\
\hline Agrimonia eupatoria & - & - & - & - & - & - & + & - & GER \\
\hline Taraxacum officinale & - & - & - & - & - & - & + & - & MOL \\
\hline Berberis vulgaris (B) & - & - & - & - & - & - & + & - & RHA \\
\hline Veronica chamaedrys & - & - & - & - & - & - & + & - & QUI BRA GER \\
\hline Galium verum & - & - & - & - & - & - & + & - & COR GER \\
\hline Euphorbia virgata & - & - & - & - & - & - & + & - & MOL \\
\hline Anemone sylvestris & - & - & - & - & - & - & + & - & GER PUB \\
\hline Dactylis glomerata & - & - & - & - & - & - & + & - & MOL LYG FAG \\
\hline Elytrigia repens & - & - & - & - & - & - & + & - & MOL ART \\
\hline Festuca rupicola & - & - & - & - & - & - & + & - & GER \\
\hline Acer negundo (B) & - & - & - & - & - & - & + & - & ROB \\
\hline Populus canescens (A) & - & - & - & - & - & - & - & 15 & POP \\
\hline Betula pendula $(\mathrm{A})$ & - & - & - & - & - & - & - & 5 & BRA FAG QUE \\
\hline Sorbus aucuparia (B) & - & - & - & - & - & - & - & 1 & BRA LON RHA \\
\hline Euonymus europaeus (B) & - & - & - & - & - & - & - & + & FAG RHA \\
\hline Equisetum telmateia & - & - & - & - & - & - & - & 15 & POP \\
\hline Galeobdolon luteum & - & - & - & - & - & - & - & + & FAG \\
\hline
\end{tabular}

Note. Legends to descriptions:

* Class mnemonic codes are given by Mucina et all., 2016.

** Syntaxons are given by Mucina et al., 2016: 1. FAG Carpino-Fagetea sylvaticae, FAG-03 Carpinetalia betuli, FAG-03A Carpinion betuli Issler 1931; 2. PUB Quercetea pubescentis, PUB-01 Quercetalia pubescenti-petraeae, PUB-01C Aceri tatariciQuercion Zolyomi 1957; 3. RHA Crataego-Prunetea Tx. 1962 nom. conserv. propos., RHA-01 Prunetalia spinosae Tx. 1952, RHA-01A Berberidion vulgaris Br.-Bl. ex Tx. 1952 nom. conserv. propos.; 4. POP Alno glutinosae-Populetea albae P. Fukarek et Fabijanic 1968, POP-02 Alno-Fraxinetalia excelsioris Passarge 1968, POP-02C Fraxino-Quercion roboris Passarge 1968.

1. 15.06.19. Solomakha I.V. Ravine system in front of the country estate „Dniprovs'ki kruchi” near the road of Stayky-Rzhyshchiv. Planting of a hornbeam 40 years, diameter $25-30 \mathrm{~cm}, 15-17$ $\mathrm{m}$ tall. A population of 150 individuals, moreover, on a plot of $7 \times 3 \mathrm{~m}-70$ individuals, and along with these other specimens grow less frequently. Individuals that are in bloom $4 / 5$ of the total numbers. Tree plantations with no grass cover, except for the orchid, nothing grows.

2. 09.06.19. Solomakha I.V. Sliding terrace on a steep slope to the bank of the River Dnieper. Poplar forest 80 years old, tree diameter $80-100$ $\mathrm{cm}$. On the plot of $10 \times 20 \mathrm{~m}$ is $150-200$ individuals, $4 / 5$ ths of the number of individuals in bloom. 
3. 16.06.19. Solomakha I.V. Not far from point 2 on the same terrace, on the plot of $10 \times 30 \mathrm{~m}$ is 200 individuals, $4 / 5$ are blooming. Planting of oak 40 years, diameter $15-30 \mathrm{~cm}$, height $17-22$ $\mathrm{m}$. Terrace on a steep slope to the River Dnieper.

4. 16.06.19. Solomakha I.V. On a steep slope $\left(45^{\circ}\right)$ of eastern exposure, poplar-hornbeam stand with low coverage of the stand -50 years, diameter $20-50 \mathrm{~cm}$, population $40-50$ pcs.

5. 16.06.19. Solomakha I.V. The area of the gutter that collects water from the slopes. Hornbeam-elm tree stand - 50 years, diameter $25-50 \mathrm{~cm}$, population $30-50$ pcs.

6. 16.06.19. Solomakha I.V. North steep slope to the R. Dnieper, $45^{\circ}$ gradient. Planting of hornbeam 40 years, height $22 \mathrm{~m}$, population $70-100$ pcs., bloom 4/5 individuals, area of $10 \times 10 \mathrm{~m}$.

7. 26.07.19. Shevchyk V.L., Solomakha I.V. The northern slope plot, $45^{\circ}$ gradient, on the slope of the forest terrace on the side of Kaniv Reservoir, area $10 \times 25 \mathrm{~m}$.

8. 23.06.19. Solomakha I.V. Western exposure slope plot, $45^{\circ}$ gradient, on the slope of the forest terrace on the Kaniv Reservoir side.

The description numbers refer to the population numbers in Table 1.

At the study area, three more populations of ten individuals were found and one population of 40 individuals, and also single individuals along the paved routes in the study area.

Syntaxonomic scheme of vegetation with the participation of Cephalanthera damasonium (MUCINA ET AL., 2016)

FAG Carpino-Fagetea sylvaticae

FAG-03 Carpinetalia betuli

FAG-03A Carpinion betuli Issler 1931 (descriptions $1,4,5,6,8)$

PUB Quercetea pubescentis

PUB-01 Quercetalia pubescenti-petraeae

PUB-01C Aceri tatarici-Quercion Zolyomi 1957 (description 3)

RHA Crataego-Prunetea Tx. 1962 nom. conserv. propos.

RHA-01 Prunetalia spinosae Tx. 1952

RHA-01A Berberidion vulgaris Br.-Bl. ex Tx. 1952 nom. conserv. propos. (description 2)

POP Alno glutinosae-Populetea albae P. Fukarek et Fabijanic 1968 (description 7)

POP-02 Alno-Fraxinetalia excelsioris Passarge 1968 POP-02C Fraxino-Quercion roboris Passarge 1968.

A number of factors (limited phytocoenotic data on locations with C.damasonium in the study area, their partly anthropogenic or spontaneous origin in the location of felled forests, quite significant influence of anthropogenic factors) did not contribute to the determination of syntaxons of the association level. All eight plots will be monitored in future and population studies will be undertaken, and more extensive descriptions will be made in future seasons along with recording the participation of ephemerals, ephemeroids and early spring-plants. All this will allow us to determine the range of available syntaxons of lower rank.

All varieties of plant communities in which C. damasonium grows in the study area, diagnosed biotopes that are included in the Emerald Network habitat list (ONYSHCHENKO, 2016), namely F3.241 (Central European subcontinental shrubs), G1.7 (thermophilic deciduous forests), G1.A1 (oak-ashhornbeam forests on eutrophic and mesotrophic soils) (BORYSENKO \& KUZEMKO, 2019; CONVENTION on THE CONSERVATION OF EUROPE'S WildLIFE AND NATURAL HabitatS, 1979; KuZEMKO ET AL., 2017). This enhances the conservation value of the area and gives an additional perspective for the creation of a nature reserve in this area (BORYSENKO \& KuZEMKO, 2019; CONVENTION ON THE CONSERVATION of EuRope's WildlifE AND NATURAL Habitats, 1979; KUZEMKO ET AL., 2017).

It should be noted that for the first time in Ukraine we have found $C$. damasonium growing in communities of class Crataego-Prunetea and Alno glutinosae-Populetea albae.

\subsection{Structure of the populations}

On July 27, 2019, two plots of populations № 1 and № 3 were studied. in order to characterize these populations.

Population №1. The area occupied by the population was $600 \mathrm{~m}^{2}$, it was a population of 87 individuals, with a density of 0,15 individuals $/ \mathrm{m}^{2}$. According to the ontogenetic structure of the population it was normal and consisted of individuals of four ontogenetic stages (j, im, v, g), right-side, generative individuals prevailed, the proportion of young vegetative individuals was negligible. Individuals were divided by ontogenetic stages as follows: generative individuals $(\mathrm{g})-78 \%$ (68 individuals), virginile (v) - 12\% (10 individuals), immature (im) - 7\% (6 individuals), juvenile - 3\% (3 individuals). This ontogenetic structure is generally characteristic of species populations (TYMCHENKo, 2007). Morphometric parameters were determined to establish the vitality of individuals; the results are presented in Table 3. Dominant are individuals of the lower class of vitality, their share is $60 \%$. The share of individuals of the intermediate and upper class of vitality was 25 and $15 \%$, respectively. By vitality the population was depressed $(Q=0,200)$. In order to further 
monitor the state of the population in the area with a high density of individuals of the species. The number of individuals in the monitoring area was 42 , the density was 1.87 individuals $/ \mathrm{m}^{2}$, which was much higher than the average density within the entire population, the maximum density was 5 individuals $/ \mathrm{m}^{2}$.

Table 3. Morphometric indicators of generative individuals

\begin{tabular}{|c|c|c|c|}
\hline Morphometric indicators & Average value & Maximum value & Minimum value \\
\hline \multicolumn{4}{|l|}{ Population 1, monitoring plot №1 } \\
\hline Height, cm & $32,7 \pm 2,4$ & 60,5 & 14,7 \\
\hline Stem diameter, $\mathrm{mm}$ & $3,2 \pm 0,3$ & 6 & 2 \\
\hline Number of sheets, pcs. & $4,1 \pm 0,2$ & 6 & 3 \\
\hline Length of leaf, cm & $6,4 \pm 0,3$ & 9,1 & 3,7 \\
\hline Width of leaf, $\mathrm{cm}$ & $2,8 \pm 0,2$ & 4,8 & 1,8 \\
\hline Number of flowers, pcs. & $5,1 \pm 0,7$ & 12 & 2 \\
\hline Number of fruits, pcs. & $3,2 \pm 0,7$ & 10 & 0 \\
\hline Percentage of fruiting & $54,8 \pm 5,3$ & 88,9 & 0 \\
\hline \multicolumn{4}{|l|}{ Population 3, monitoring plot №2 } \\
\hline Height, cm & $42,3 \pm 2,1$ & 56 & 24 \\
\hline Stem diameter, mm & $3,3 \pm 0,2$ & 4 & 2 \\
\hline Number of sheets, pcs. & $4,3 \pm 0,1$ & 5 & 4 \\
\hline Length of leaf, cm & $7,4 \pm 0,3$ & 9,5 & 5 \\
\hline Width of leaf, cm & $3,1 \pm 0,2$ & 4,7 & 1,6 \\
\hline Number of fruits, pcs & $6,4 \pm 0,9$ & 13 & 2 \\
\hline
\end{tabular}

Population №3. The area occupied by this species population was $750 \mathrm{~m}^{2}$, number of individuals in the populations was $400-500$, density was $0,5-0,7$ individuals $/ \mathrm{m}^{2}$. Ontogenetic structure in this population wasn't studied. The individuals were divided according to their vitality as follows: $12,5 \%$ were lower class individuals, $37,5 \%$ were intermediate and $50 \%$ were higher class. The population was prosperous $(\mathrm{Q}=0,438)$. In the $4 \mathrm{~m}^{2}$ monitoring plot, 42 individuals were identified. The density of individuals was 10,5 individuals $/ \mathrm{m}^{2}$, which, as in the previous population, far exceeds the average density. The morphometric indicators of the generative individuals of this population are shown in Table 3.

Comparison of the state of the studied populations at the north eastern boundary of the species range with populations from other regions indicates a higher number of individuals at greater densities in these populations. According to our data, and that of other researchers, in the main part of the area most $C$. damasonium populations are characterised by low numbers and densities of individuals, from a few tens to one hundred individuals, with a density not exceeding 0.1 individuals $/ \mathrm{m}^{2}$, although there are rarely populations of more than 1000 individuals or, conversely, of only single individuals (RALO, 2002; TyMchenko, 2007; Red Book of THE
RUSSIAN FEDERATION, 2008; RANKOU, 2011; ŠEgOTA ET AL., 2012; PODGÓRSKA, 2015). On the ontogenetic spectrum most populations in Ukraine are characterized by the absence of young vegetative individuals ( $\mathrm{j}$, sometimes $\mathrm{j}$ and $\mathrm{im}$ ), while the studied populations had full-member and young vegetative juvenile (j), immature (im), adult vegetative (virginile, v) and generative (g) plants. The presence of young vegetative plants indicates favourable ecological-coenotic conditions for the restoration of populations. The low proportion of young vegetative plants is characteristic of many terrestrial orchids and explains the low survival of seedlings and young vegetative plants, as well as a longer plant life in the virginile and generative ontogenetic stages. However, all species populations are characterized by the predominance, in the ontogenetic spectrum, of generative individuals, and occasionally vegetative adults (virginile) (RALO, 2002; TYMCHENKO, 2007; PoDGóRSKA, 2015; POPOVA, 2015).

As for the vitality structure of the populations of $C$. damasonium then this research was conducted only within Ukraine. In the main part of the range (western regions of Ukraine and the Crimea Mountains) $55 \%$ populations are depressive in terms of vitality structure, $45 \%$ - prosperous and equilibrium (Tymchenko, 2007). Populations at 
the limit of the range are similar in vitality structure, population №1 - depressed, №3 - prosperous. The individuals of intermediate and higher class of vitality are dominant in population № 3 and this is confirmed by higher values of all morphometric parameters for individuals in this population. The better state of population №3 is also confirmed by the higher number and density of individuals, which indicates more favourable ecological and coenotic conditions at this site.

\section{Conclusions}

New populations of $C$. damasonium on the north eastern boundary of its distribution have been found. These populations confirm the existence of this species in the 1930s, and supplement the information available in the scientific literature on the distribution of this species and indicate the possibility of long-term functioning (about a hundred years) of local populations under suitable growing conditions of this rare species on the edge of its range. These identified populations are characterised by high numbers and densities of individuals, the presence of young vegetative plants and individuals of high vitality. Comparison of the ecological and coenotic conditions and the population structure of $C$. damasonium at its limit and in the main range of its distribution show they are similar. The peculiarity of this locality is the high number of individuals in most of the identified populations, which may be due to favourable ecological-coenotic conditions and the absence of anthropogenic influences. The identified habitats of the species in this study need protection. The information presented in this article can serve as the scientific justification for the creation of a botanical reserve. In the future, it is planned to continue a comprehensive study of all identified populations of Cephalanthera damasonium and to monitor them.

\section{References}

Abduloeva O.S., Solomakha V.A. 2011. Phytocenology. Textbook. Fitosociocentr. Kiev. [in Ukrainian].

Bayrak O.M., Stetsiyk N.O. 2005. Atlas of rare and endangered plants of Poltava region. Verstka Poltava [in Ukrainian].

Borysenko K.A., Kuzemko A.A. 2019. Areas offered for inclusion in the Emerald Network (Emerald Network) of Ukraine (shadow list, part 2). LAT \& K. Kiev [in Ukrainian].

Braun-Blanquet J. 1964. Pflanzensoziologie, Grundzuge der Vegetationskunde. 3rd Edition. Springer-Verlag. Berlin.

Chopyk V.I., Myakushko T.Ya., Solomakha T.D. 1999. Herbarium: history, creation, functioning. Fitosociocentr. Kiev. [in Ukrainian].

Chornej I.I., Budzhak V.V., Tokarjuk A.I., Nikirsathe T.D. 2003. Genus Cephalanthera Rich. (Orchidaceae) in the flora of Bukovyna - chorological characteristic. Scientific Herald of Chernivtsy University. Biology, 169: 111-119. [in Ukrainian].
Climate of Ukraine. Eds. V.M. Lipinsky, V.A. Dyachuk, V.M. Babichenko. 2003. Raevsky Publishing House. Kiev. [in Ukrainian].

Convention on the Conservation of Europe's Wildlife and Natural Habitats. 1979. Bern.

Ecological Encyclopedia. Ed. A.V. Tolstouxova. 2006. V.1. Center for Environmental Education and Information Kiev [in Ukrainian].

Flora of China. 2009. Science Press, Beijing, and Missouri Botanical Garden Press, 25: 174-177.

Grun' F.0. 1946. Relic elements in the flora of the Dykan forests. Botanical Journal USSR Academy of Sciences. 6, 2: 207-212. [in Ukrainian].

Kuzemko A., Sadohurs'ka S., Vasylyuk 0. 2017. Explanatory guide habitat resolution number 4 of the Berne Convention, endangered and need special protection measures. The first version of an adapted unofficial translation from English (the third draft of the official 2015 version). Kiev. [in Ukrainian].

Kuzemko A.A., Borysenko K.A. 2019. Designing and conservation areas network Emerald (Emerald Network). LAT \& K. Kiev [in Ukrainian].

Kuzemko A.A., Didukh Ya.P., Onyschenko V.A., Yan Sheffer. 2018. National habitat catalogue of Ukraine. FOP Klimenko Yu.Ya. Kiev. [in Ukrainian].

Mosyakin S.L., Fedoronchuk M.M. 1999. Vascular plants of Ukraine. A nomenclatural checklist. M. G. Kholodny Institute of Botany, National Academy of Sciences of Ukraine, Kiev.

Mucina L., Bultmann H., Dier.en K., Theurillat J.-P., Raus Th., Cărni A., Šumberova K., Willner W., Dengler J., Garcia R.G., Chytry M., Hajek M., Di Pietro R., Iakushenko D., Pallas J., Daniels F.J.A., Bergmeier E., Guerra A.S., Ermakov N., Valachovib M., Schaminee J. H.J., Lysenko T., Didukh Y.P., Pignatti S., Rodwell J.S., Capelo J., Weber H.E., Solomeshch A., Dimopoulos P., Aguiar C., Hennekens S.M., Tichy L. 2016. Vegetation of Europe: hierarchical floristic classification system of vascular plant, bryophyte, lichen, and algal communities. Applied Vegetation Science, 19, S1: 3-264.

Myrkyn B.M., Naumova L.H., Solomeshch A.Y. 2001. Modern science of vegetation. Logos. Moscow. [in Russian].

National Atlas of Ukraine. 2008. Ed. L.G. Rudenko. DNVP Kartografiya, Kiev [in Ukrainian].

Nedorub O.Yu. 1998. Vegetation of Dykankas' woodland. Ukrainian Botanical Journal, 55, 2: 207-212. [in Ukrainian].

Onyshchenko V.A. 2016. Coverage of habitats from Resolution 4 of the Bern Convention with Emerald Network of Ukraine. Conference: Classification of vegetation and habitats of Ukraine as a scientific basis for biodiversity conservation. Kiev. [in Ukrainian].

Podgórska M. 2015. New locality of Cephalanthera damasonium (Orchidaceae) on the former iron-ore mining remnants. Fragmenta Floristica et Geobotanica Polonica, 22, 1: 106-109.

Popova O.M. 2015. Finds of Cephalanthera damasonium and Platanthera $\times$ hybrida (Orchidaceae) in National Nature Park Tuzlovski Limany, the status of their populations and conservation perspectives, Ukrainian Botanical Journal, 72, 4: 357-363. [in Ukrainian].

Ralo V 2002. The location of rare plant species on Voronyaki (North-Western Podolia region). Scientific bases of biodiversity conservation, 4: 95-102. [in Ukrainian].

Rankou H. 2011. Cephalanthera damasonium. The IUCN Red List of Threatened Species 2011: e.T176005A7169186. Downloaded on 12 February 2020.

Red Book of the Russian Federation (plants and mushrooms). Ed. Myhajlov K.G. Ministry of Natural Resources and ecology of the Russian Federation and Rosprirodnadzor, 2008. [in Russian].

Red Book of Ukraine. Plant life. 2009. Ed. Didukh Y.P. Globalkonsaltyng. Kiev. [in Ukrainian]. 
Šegota V., Hršak, V., Alegro, A. 2012. Cephalanthera damasonium (Mill.) Druce in Mediterranean evergreen vegetation. Natura Croatica: Periodicum Musei Historiae Naturalis Croatici, 21, 1: 247-254.

Semenishchenkov Yu. A. 2019. On the record of Cephalanthera damasonium (Orchidaceae) in Bryansk region. Botany Journal, 104, 9: 1494-1496. [in Russian].

Shefferson R.P., Jacquemyn H., Kull T., Hutchings M.J. 2020. The demography of terrestrial orchids: life history, population dynamics and conservation, Botanical Journal of the Linnean Society, 192, 2: 315-332.

Skvorczov A. K. 1977. Herbarium: A Guide to Methods and Techniques. Nauka Moscow. [in Russian].

Solomakha I.V. 2019. New localities of 2 rare flora species of Ukraine in the Right-Bank Forest-Steppe. Abstracts of the International scientific-practical conference "Restoring, protecting and preserving of the plant diversity of forests of Ukraine in conditions of technological impact and climate change". Kiev. [in Ukrainian].

Stroh P.A., Leach S.J., August T.A., Walker K.J., Pearman D.A., Rumsey F.J., Harrower C.A., Fay M.F., Martin J.P., Pankhurst T., Preston C.D., Taylor I. 2014. A Vascular Plant Red List for England. Botanical Society of Britain and Ireland, Bristol.

The Red book of the republic of Moldova. Third edition. 2015.
Stiinta. [in English and Moldovan]

Tymchenko I.A. 2007. The genus Cephalanthera of Ukrainian flora: distribution, ecologo-coenotic peculiarities, structure of population and conservation. Scientific Journal of Herald of Tver State University, 36, 8: 164-167.

Vakhrameeva M.G., Tatarenko I.V., Varlygina T.I., Torosyan G.K., Zagulskii M.N. 2008. Orchids of Russia and adjacent countries (within the borders of the former USSR). Ruggell, Liechtenstein.

WCSP. 2020. World Checklist of Selected Plant Families. Facilitated by the Royal Botanic Gardens, Kew. Retrieved February 12, 2020, from http://wcsp.science.kew.org.

Zarzycki K., Szeląg Z. 2006. Red list of the vascular plants in Poland. [in:] Z. Mirek, K. Zarzycki, W. Wojewoda, Z. Szeląg (eds.) Red list of plants and fungi in Poland. W. Szafer Institute of Botany, Polish Academy of Sciences, Kraków: 9-20.

Zlobin Yu.A. 1989. Principles and methods for studying coenotic plant populations. Kazan University Publishing House. Kazan [in Russian].

Zlobin Yu.A. 2018. An algorithm for assessing the vitality of plant individuals and the vitality structure of phytopopulations. Chornomors'k. bot. z. 14 (3): 213-226. [in Ukrainian]. 